\title{
Developing Sustainable Agricultural Sector, as an Impetus for Macedonia`s Economic Growth
}

\author{
Biljana Ciglovska ${ }^{1}$
}

\begin{abstract}
Agriculture is one of the most promising sectors in Macedonian economy, considering the fact that the average share of agriculture in GDP is $10 \%$ and it accounts for $17.87 \%$ of the total employment. Furthermore, if agro-processing is included the contribution to the GDP increase to $16 \%$. Macedonia has $25.713\left(\mathrm{~km}^{2}\right)$ country area, $12.630\left(\mathrm{~km}^{2}\right)$ or $50.08 \%$ agricultural land, from which $16.4 \%$ is arable land, $1.51 \%$ permanent cropland and $39.57 \%$ forest area. With $42.7 \%$ rural population, the agriculture has important social and economic functions in Macedonian economy. Despite the third place that agriculture takes within the Macedonian economy referred to a small sector, its potential and opportunities are far greater than the current state of this sector and the results it provides. The significance of Macedonian agriculture is underestimated by official authorities. According to the World Bank Group Report for "Green Growth country assessment", Macedonian agricultural sector is one of the sectors that need to be transformed, due to the unsustainable developing strategies used by the authorities. Therefore, the objective of this paper is to emphasize the significant advantages, strengths and the unused potential of the Macedonian agricultural sector and to provide guidelines and suggestions for turning it into growth leading sector on a sustainable basis. Sustainable development is not an abstract concept; it is the roadmap for responsible acts at a national level. For that purpose, the role of the most important stakeholders in developing process will be emphasized and discussed.
\end{abstract}

Keywords: sustainable development, agriculture, reforms, economic growth

\section{Introduction}

The Republic of Macedonia, formerly a part of Yugoslavia from which it declared independence in 1991 is situated in the central part of the Balkan Peninsula (Southeastern Europe). According to the World Bank categorization, the Republic of Macedonia is upper middle-income country, which is characterized by large and high mountain massifs giving way to extensive, flat valleys and plains. Macedonia has $25.713\left(\mathrm{~km}^{2}\right)$ country area, 12.630 $\left(\mathrm{km}^{2}\right)$ or $50.08 \%$ agricultural land, from which $80 \%$ is arable land and gardens, $12 \%$ meadows, 5\% vineyards, and 3\% orchards (State Statistical Office, 2017). With 42.7\% rural population, and with 10\% share of GDP, the agricultural sector remains important and very promising sector of the country. The agricultural sector plays an important role in Macedonia's economy, although the small-scale and fragmented nature of farming is its general characteristic. If we go back in Macedonian history, we can note that during the Kingdom of Yugoslavia, Macedonia compared to other areas within the Kingdom was the most undeveloped area in economic and educational-cultural terms. It was a typical agrarian area in which economic and cultural backwardness prevailed. Agriculture, which even then had leading positions in the Macedonian economy, had an exclusively extensive 
character. After the Second World War, the collectivization of the Macedonian village, carried out according to the Soviet model of agriculture, was one of the measures of the Yugoslav agrarian policy that caused far-reaching negative consequences in the overall development of the Republic of Macedonia.

Prior to independence agricultural sector development was constrained by the policies of the Former Yugoslav Federation, including the policy of achieving self-sufficiency in food production, the misguided pursuit of scale efficiencies through inefficient Agro-Kombinats (AKs), and controls over trade and input and output prices (World Bank, 2002).

After proclaiming independence in 1991, Macedonia has realized extensive structural reforms in agriculture, including partial privatization of $\mathrm{AKs}$ and a major reduction in the level of budgetary support. The new Macedonian agricultural policy was based on market prices and frees pricing of agricultural products, while the market interventions occur in the form of tariff protection and trade restrictions as well as price subsidies for some agricultural products (Ericson, 2005). Due to these reforms and changes in the legal, institutional and economic frameworks, significant effects and benefits were achieved within the agricultural sector but with a very slow pace. The WTO membership as well as the aim of Republic of Macedonia for EU integration, inevitably lead to changes and adjustments in the agricultural policy, due to which are brought agricultural strategies oriented to the rural development, increasing and promoting the competitiveness, the quality and safety of agricultural products and food, rational and sustainable use of resources, increasing the volume of GDP, securing conditions for free trade and Most Favorite Nation (MFN) treatment of the Macedonian export. The Macedonian Ministry of Agriculture, Forestry and Water Economy (MAFWE), together with the Agency for Financial Support of Agriculture and Rural Development (AFSARD) and the Agency for Food and Veterinary (AFV) are the main institutions for agricultural policy development and implementation of periodical strategies for agricultural and rural development.

Today, Macedonian agriculture is characterized with dual structure in which dominate small farms with a high level of fragmentation and with an average farm size of approximately 1.7 hectares, scattered over two to three plots, which lead to inefficient use of farm land (WTO, 2014). The largest share in agricultural output (over 50\%) belongs to fruits and vegetables and tree crops, and the livestock sector accounts for $7 \%$ in the total agricultural output. The main crops include cereals, industrial crops (mainly tobacco), fodder, fruit and vegetables, and they are the most important exported and competitive agri-food products. Even before the breakup of the Former Yugoslavia, the Republic of Macedonia was a major agricultural supplier for the whole federation. But, at the same time Macedonia is also agri-food importer especially for meat and edible meat offal (Dimitrievski, Kotevska, Stamenkovska, Tuna, Nacka, 2015). Exports of agriculture and food products in 2016 constituted $12.25 \%$ of Macedonia's total exports. The main export products from Macedonia are fresh and processed vegetables and fruits $34.8 \%$ of total agricultural exports), tobacco $24 \%$, grains $13.5 \%$, and beverages $12 \%$. The main import products are meat (beef, poultry, and pork accounted for $20 \%$ of total agriculture imports), fruits and vegetables, grains, coffee, tea, and spices (Invest in Macedonia, 2016). Macedonia has the potential to generate even more substantial export incomes from high-value crops like fruit and vegetables and the organic products, but unfortunately the land capacities and other natural resources are not fully utilized. 
Numerous weaknesses hinder the development of Macedonian agricultural sector such as, the out-dated equipment and technology, low productivity level, lack of value added agricultural products, lack of seasonal labor, increased aging and migration of rural population and low level of education and management skills of the rural population.

\section{The Place and the Relevance of Agriculture in the Macedonian Economy}

Agriculture is an important development tool for achieving economic development goals, and the opportunity to accelerate economic growth, overcoming poverty and enhancing food security. Agriculture, understood as a systematic breeding of beneficial plants with the help of human activity, is the oldest activity on the planet Earth and today is the basis for the existence of great part of the world's population (Kjosev, 2015). The development of scientific thought about agriculture and its role in the overall socio-economic development has begun in the old age. Ancient Chinese civilization also left written texts through which the development of agriculture and its place in the country can be seen. Thus, Shan Yan (IV century BC) in his book "Guide of the Monarchs" writes that "... the essence of a good state governor consists in directing all thoughts towards the agriculture". According to him, the agriculture is supposed to be developed with better land processing, implementing lower taxes, and putting the agriculture trade under state control in order to avoid the middlemen and usurers.

The conventional approach to the roles of agriculture in development concentrated on agriculture's important market-mediated linkages: (a) providing labor for an urbanized industrial work force; (b) producing food for expanding populations with higher incomes; (c) supplying savings for investment in industry; (d) enlarging markets for industrial output; (e) providing export earnings to pay for imported capital goods; and (f) producing primary materials for agro-processing industries (Johnston and Mellor, 1961; Ranis et al., 1990; Delgado et al., 1994; Timmer, 2002). The relative relevance of the agricultural sector in the economy differs from country to country, and generally it could be between 3 to $40 \%$ of the total production value and up to $70 \%$ from the total work force. Therefore, the agriculture plays key role in the development of each national economy.

Agriculture is a sector that absorbs and mitigates the effects of socio-economic and structural changes occurring in the Republic of Macedonia within the industrial sector and other sectors in the Macedonian economy. In the period before and after the independence of the Republic of Macedonia, the agricultural sector has a significant contribution to the overall development of the country, given the fact that Macedonia is a typical agrarian area in which agriculture with extensive character holds leading positions in the economy. In the Macedonian agricultural sector, small family-owned farms are the dominant ones, which account for most of the agricultural production. In the direction of their development, the Law on transformation of agricultural enterprises with social capital and collective farms was adopted, aiming privatization and restructuring of the non-privately owned agricultural sector. The importance and significance of one sector for the development of the national economy depends from its participation and contribution in creating the Gross domestic product (GDP).

The share of agricultural production in the GDP of the Republic of Macedonia varies in the period before and after its independence. The various trends are due to the changes 
that occur in the economic structure of the Republic of Macedonia at different periods. Such structural changes characterize the transition process of all developing countries within which, the participation of the agricultural sector is gradually reduced on account of the participation of the industrial and service sector. Thus, during the 1950s, agriculture accounted for $40 \%$ of the GDP, while during the 1980 s the share fell significantly under the influence of the transition process, the acceptance of technological innovations, changes in general economic conditions and the like.

But, exactly the technological changes together with the international trade in agricultural products are a driving force for accelerated economic development, and the export of agricultural products is a generator that should instigate positive changes.

During the 1990s, respectively, after the independence of the Republic of Macedonia, the share of agriculture again increased to $17 \%$, which is due precisely to the changes that occur in the economic structure of the Republic of Macedonia. Namely, after the independence, the agricultural sector is intensively developing, when a large part of the workforce is reoriented towards this activity, and numerous individual farms and small farmers are formed as drivers of development, while the development of industry in that period is declining. According to the research done by (M. Micevska, D. Eftimoski and T.P. Mircevska, 2002), before the transition period of the Republic of Macedonia the agricultural sector share in creating the GDP was around $9 \%$ in order to continue to be significant sector during the 1990 s and 2000 s, which share continues to grow up to 10 $12 \%$.

From the data in Table 1 it can be seen that today, the role of the agricultural sector in the economy of the Republic of Macedonia is significant taking into account its share in GDP of almost $10 \%$, which is relatively stable compared to the agricultural sector in the EU-28 whose average share in GDP is 1.6\% (EUROSAT, 2017) ${ }^{1}$.

Table1. The share of agricultural production in Macedonian GDP during the period 1999-2016 (in \%)

\begin{tabular}{|l|c|c|c|c|c|c|c|c|c|c|c|}
\hline Year & 1999 & 2000 & 2001 & 2002 & 2003 & 2004 & 2005 & 2006 & 2007 & 2008 & 2009 \\
\hline Agriculture & 11.7 & 10.5 & $\mathbf{9 . 8}$ & $\mathbf{1 0 . 0}$ & $\mathbf{1 1 . 7}$ & $\mathbf{1 1 . 3}$ & $\mathbf{1 2 . 0}$ & $\mathbf{1 2 . 0}$ & $\mathbf{9 . 4}$ & $\mathbf{1 0 . 4}$ & $\mathbf{9 . 7}$ \\
\hline Processing industry & 26.7 & 27.0 & $\mathbf{1 6 . 9}$ & $\mathbf{1 5 . 9}$ & $\mathbf{1 5 . 6}$ & $\mathbf{1 5 . 0}$ & $\mathbf{1 5 . 6}$ & $\mathbf{1 6 . 2}$ & $\mathbf{1 8 . 4}$ & $\mathbf{1 7 . 8}$ & $\mathbf{1 4 . 1}$ \\
\hline Services & $\mathbf{5 2 . 8}$ & $\mathbf{5 4 . 2}$ & $\mathbf{5 6 . 4}$ & $\mathbf{5 7 . 5}$ & $\mathbf{5 6 . 0}$ & $\mathbf{5 7 . 7}$ & $\mathbf{5 7 . 6}$ & $\mathbf{5 7 . 7}$ & $\mathbf{5 6 . 0}$ & $\mathbf{5 7 . 0}$ & $\mathbf{5 7 . 0}$ \\
\hline Year & 2006 & 2007 & 2008 & 2009 & 2010 & 2011 & 2012 & 2013 & $\mathbf{2 0 1 4}$ & $\mathbf{2 0 1 5}$ & $\mathbf{2 0 1 6}$ \\
\hline Agriculture & $\mathbf{1 2 . 0}$ & $\mathbf{9 . 4}$ & $\mathbf{1 0 . 4}$ & $\mathbf{9 . 7}$ & $\mathbf{1 0 . 1}$ & $\mathbf{9 . 5}$ & $\mathbf{9 . 1}$ & $\mathbf{1 0 . 0}$ & $\mathbf{1 0 . 2}$ & $\mathbf{9 . 7}$ & $\mathbf{9 . 1}$ \\
\hline Processing industry & 16.2 & $\mathbf{1 8 . 4}$ & $\mathbf{1 7 . 8}$ & $\mathbf{1 4 . 1}$ & $\mathbf{1 8 . 8}$ & $\mathbf{1 8 . 9}$ & $\mathbf{1 5 . 4}$ & $\mathbf{1 5 . 0}$ & $\mathbf{1 6 . 0}$ & $\mathbf{1 6 . 9}$ & $\mathbf{1 7 . 3}$ \\
\hline Services & $\mathbf{5 7 . 7}$ & $\mathbf{5 6 . 0}$ & $\mathbf{5 7 . 0}$ & $\mathbf{5 7 . 0}$ & $\mathbf{4 6 . 2}$ & $\mathbf{5 2 . 5}$ & $\mathbf{5 6 . 3}$ & $\mathbf{5 5 . 0}$ & $\mathbf{5 3 . 8}$ & $\mathbf{5 3 . 6}$ & $\mathbf{5 3 . 2}$ \\
\hline
\end{tabular}

Source: State statistical office of the Republic of Macedonia

The Republic of Macedonia has certain comparative advantages in agricultural production, precisely in view of the low price of labor engaged in agriculture, fertile soil, experienced producers, certain natural resources and infrastructure facilities. Such already given comparative advantages should be used in the direction of creating or gaining competitive advantages. With the above mentioned type of structure and the corresponding comparative advantages, the Macedonian agricultural sector despite the significant participation in the international trade, in which it is the third most important

${ }^{1}$ Available at: http://ec.europa.eu/eurostat/statistics-explained/index.php/National_accounts_and_GDP 
in the export and where the Republic of Macedonia appears as an exporter of laborintensive agricultural products, it still has insufficient capacity utilization as a starter of the economic development of our country. This is a problem that all developing countries face with, due to the lack of investments that could improve the production process in the direction of creating products with higher level of processing and greater value and exporting them on foreign markets at higher prices.

In this way, the agricultural sector of each country should become a major catalyst for the development and advancement of the economy. The participation of the Republic of Macedonia in the global trade in agricultural products should not be underestimated, considering the fact that the opportunities and capacity of the agricultural sector are not fully used. As shown in Figure 1, within the total export of the Republic of Macedonia, agricultural products participate with $15-17 \%$, while on the import side they account for $12-14 \%$, which shows that the Republic of Macedonia simultaneously appears as an exporter and as a net importer of agricultural products, which percentage of participation is characteristic for developing countries.

\section{6}

(a) Exports (f.o.b.)

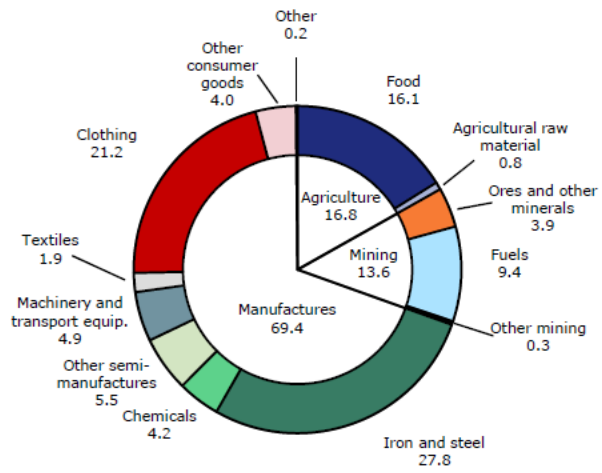

(b) Imports (c.i.f.)

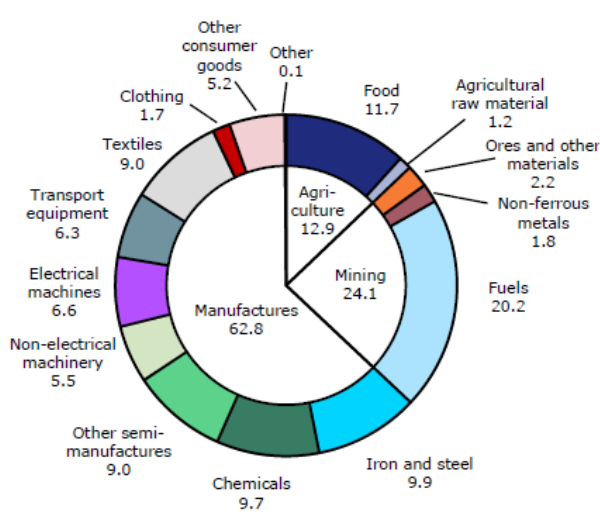

2012
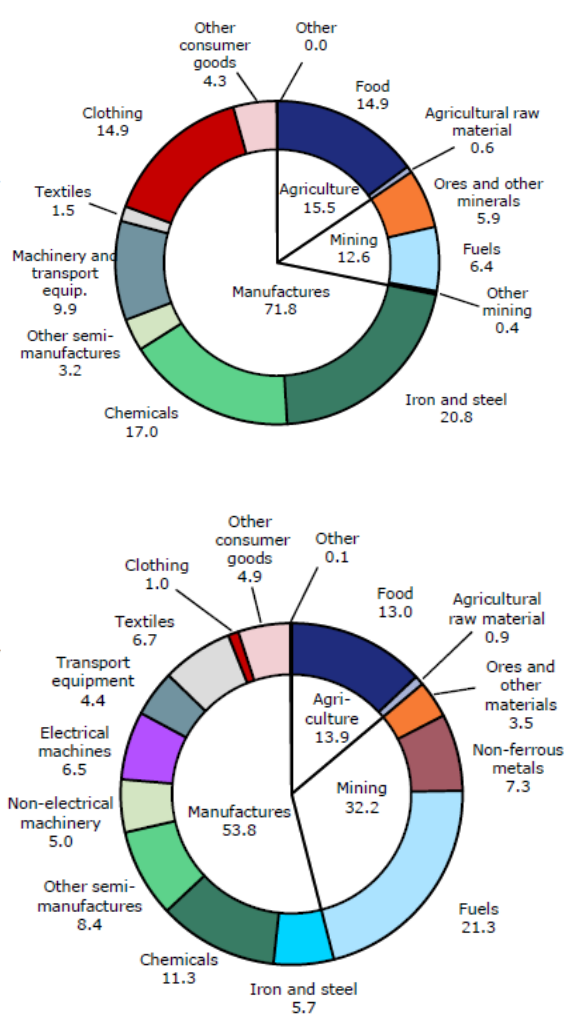

Figure 1. Composition of merchandise trade, 2006 and 2012

Source: WTO Secretariat calculations, based on UNSD, comtrade database (SITCF Rev.3). 
The export of Macedonian agricultural products is mostly directed to EU countries and neighboring countries of the former Yugoslavia, with Serbia, Montenegro, Germany, Greece, the United States, Italy, Croatia and Slovenia as the most important export trade partners, which in the total export of the Republic of Macedonia, account for $73.7 \%$. (USAID, Ministry of Economy of the Republic of Macedonia, 2005, 2006).

Except for these countries, the export of agricultural products is also directed to the neighboring countries, Albania, Bulgaria, Greece and Turkey, with which the Republic of Macedonia has concluded free trade agreements in order to facilitate mutual exchange. Regarding the agricultural imports, the main trading partners are Serbia, Germany, Bulgaria, Greece, Slovenia, Turkey, Poland and China. Macedonia should constantly fight for greater participation in the international trade in agricultural products, based on the comparative advantages it possesses in the agricultural sector and the maximum utilization of them through the creation and implementation of an appropriate agricultural and foreign trade policy.

\section{Literature and Conceptual Reviews}

There is an old proposition that agriculture growth contributes to overall economic development. Even the old Chinese civilization overlooks the agriculture as a very important activity which has to be under governor control, whose main responsibility should be providing food for the people. Also, many early analysts (Rosenstein-Rodan, 1943; Lewis, 1954; Scitovsky, 1954; Hirschman, 1958; Jorgenson, 1961; Fei and Ranis, 1961) highlighted agriculture because of its abundance of resources and its ability to transfer surpluses to the more important industrial sector. Moreover, the agricultural sector is in various development reports often advocated as a vital tool and crucial sector for generating economic growth and fighting poverty (World Bank, 1981 and 2008). During different periods, the role of agriculture in the process of economic growth has been considered quite differently.

In most early work on economic development, agriculture is often ignored and industrial development is often emphasized as the main driver of economic growth (Self and Grabowski, 2007; Tiffin and Irz, 2006). Industrialism is a governing doctrine of socioeconomic development for seven decades of the 20th century, and not only in Europe but also throughout the world (Kjosev, 2015). Until the mid-20th century it was believed that agriculture is unproductive and therefore all investments and policies are guided towards the industry as highly productive activity.

However, this relation is always subject to debate. Some literature emphasizes the importance of increases in agricultural productivity as precondition for economic growth. According to this literature - mainly in developing countries, where the agricultural sector accounts for a large share of the workforce and accounts for roughly $25 \%$ of the value added in the economy - growth in agricultural productivity causes significant aggregate effects and will therefore also influence the general economic growth within a country (Gollin, 2010; Diao et al., 2010). Also, very little research shows that there might be reversed causal relation between general economic growth and changes in agricultural productivity and that agriculture might also benefit from wider process of economic growth (Tiffin and Irz, 2006). A number of empirical studies confirmed the leading role of 
agriculture in economic development. Using data from various countries in the period 1960-1995, (Self and Grabowski, 2007) find that agricultural modernization (e.g. fertilizer and tractor use intensity) has an impact on the long-run economic growth. Agricultural sector has already made a significant contribution to the economic prosperity of developed countries and its role in the economic development of developing and less developed countries is of vital importance.

According to Dr. Bright Singh, "Increase in agricultural production and the rise in the per-capita income of the rural community, together with the industrialization and urbanization, lead to an increased demand in industrial production". The history and experience of England, USA, Japan and many developing and underdeveloped countries in clear evidence that agricultural revolution could precede the industrial revolution. It demonstrates that, industrial and agricultural developments are not alternatives but are complementary and are mutually supporting with respect to both inputs and outputs. According to Prof. Kindlerberger, Todaro, Lewis and Nurkse etc, agriculture makes its contribution to economic development in several ways: by providing food and raw materials to non-agricultural sectors of the economy; by creating demand for goods produced in non-agricultural sectors, by the rural people due to their increased purchasing power; by providing investable surplus in the form of savings and taxes to be invested in non-agricultural sector; by earning valuable foreign exchange through the export of agricultural products; by providing employment to a vast army of uneducated, backward and unskilled labor.

\section{Perspectives and Challenges of Macedonian Agriculture}

The Government of Macedonia considers agriculture a target area for future investments, growth and development. In 2014 the Government of Macedonia adopted a six-year National Strategy for Agriculture and Rural Development (NSARD) 2014 2020, as a continuing strategy from the previous one adopted for the period 2007-2013, with the same strategic aim, to strengthen the ability of Macedonia's agricultural sector to compete in the EU and other regional markets and to promote sustainable development of rural areas and secure sustainable exploitation of natural resources (MAFWE, 2014). The strategy, which is a pre-requisite for receiving EU Instrument for Pre-accession Assistance (IPA) II assistance in agriculture, also aims at improving the marketing of agricultural products and implementation of minimum quality standards according to the EU approximated Law on quality of agricultural products and respective by-laws. On the road to the EU, Macedonia must implement reforms and adapt to EU rules, policies and standards, especially with regard to the development of a sustainable agricultural sector, bearing in mind the importance of agriculture to the EU. In that direction, many funds, projects and initiatives for improving the agricultural sector and turning it into the primary sector in the economy are available to Macedonia.

According to the analysis done within the NSARD 2014-2020, Macedonian Agriculture has numerous strengths and opportunities for further development and improvement which have to be put to use, but unfortunately there are numerous weaknesses and threats in the same time that inhibit the agricultural development and which have to be removed and surpassed. 


\section{STRENGHTS}

- Stable share of agriculture, forestry and food processing sector accounts for an important part in the national GDP; - Growth of dairy and fruit and vegetable production value; - Good access and distribution links to the European markets, crossroads of transport routes and main European transport corridors;

- Good climatic conditions for agriculture and variety of regions with diverse opportunities for agriculture production;

- Ownership of agricultural land and assets attributed mainly to private farmers;

- Favorable natural conditions and experience for development of the crop and livestock sectors;

- Location of the processing capacities near the urban centers benefits labor mobility (availability of transport and services network);

- Prominent role of the small and medium food processing enterprises as more flexible and competitive economic agents;

- Long tradition in the production of various primary products and processed foods and high demand for agriculture and food products and on the traditional regional markets;

- Positive efforts for establishing horizontal links among processors and primary producers (contract farming);

- High natural potential for timber production;

Well-established and active associations of agriculture producers; food processors, private forest owners, and Chambers of Commerce;

- Strong Government commitment for agriculture development with complete set of governing rules, registers and increasing budgetary support for sector development;

\section{OPPORTUNITIES}

- Increasing business interest in agriculture and food processing;

Growing demand for investments in agriculture machinery and equipment, perennials establishment and improvement of varieties;

- Potential for structural improvement, such as land consolidation, producer groups, cooperatives;

- Introduction of new products and technologies in agriculture, food processing industry and forestry;

- Promoting changes of production and product ranges to match increasing market and quality requirements;

- Growing SME's potential for their development and diversification of activities in agriculture;

- Strengthening of the role of extension and advisory services and research;

- Increasing urge for introduction of advanced quality standards HACCP, ISO, among the food processing enterprises;

- Existing VET schools in agriculture have potential for playing a key role in provision of training to farmers due to their close location of the facilities and human capacity sufficiently skilled for technological production practices and can provide advisory services.

Figure 2. SWOT Analysis of Macedonian Agricultural Sector

Source: Ministry of Agriculture, Forestry and Water Economy, NS ARD 2014-2020

\section{WEAKNESSES}

- Unfavorable farming structure with mixed agriculture production on small and disbursed land plots;

Low efficiency and productivity of agriculture and food sector;

Low use of agricultural machinery and highly depreciated mechanization;

Weak farm management practices in terms of utilization of fertilizers and crop protection and use of quality certified seeds/planting material;

High labor intensiveness (dependence on family labor);

Absence of post harvesting capacities and marketing skills at farm level;

- Low liquidity and lack of capital for small holder farmers to undertake new modernization investments;

- Seasonal supply of raw materials contributing to overcapacities in the food processing establishments;

Large number of agriculture livestock farms and food processing capacities non-compliant with the EU relevant standards;

- Over regulated forestry sector and underdeveloped management of state forests;

- Lack of machinery for forest management;

Weak forest management practices in terms of forest protection and utilization;

- Underdeveloped system for adult vocational training in agriculture, food industry and forestry and insufficient outreach of the extension services and advisory services;

Lack of appropriate demonstrative farms to carry out the practical trainings and the human potential in the education sector lacks of knowledge in EU standards and environmental practices;

- Underdeveloped input and output markets and market infrastructure

\section{THREATS}

- High land fragmentation of agriculture and forest land plots;

- Ageing labor force in agriculture; and unskilled labor;

- Lack of seasonal labor in harvesting period and in food - processing seasonal peaks;

- Modest efforts of commercial banks for agriculture finance;

- High collaterals;

Great degree of small-scale farms, many of them producing mainly for self-subsistence and economically not viable;

- Lack of interests for establishment of cooperatives by the small-holder farmers;

Poor market position of small producers depending on vendors to market their products, long market chains and lack of marketing services including information;

- Decrease of labor availability, and increase in the labor, input and land costs;

- Increased competition on the domestic market;

Limited providers of new agriculture and food processing machinery;

- Lack of innovations and technology transfers due to high osts of research and small market opportunities. 
The numerous weaknesses and disadvantages of the Macedonian agricultural sector have to be turned into sustainable advantages. According to the World Bank Group Report for "Green Growth" country assessment (WB Group, 2014), the agricultural sector is one of the sectors that need to be transformed to achieve sustainable development and growth. Macedonia is using unsustainable strategies for agricultural development. Besides that, the small and fragmented farms and inadequate land markets limit agricultural productivity, while government subsidy programs are poorly designed to achieve their stated objectives. For creating more competitive, export-oriented agricultural sector, adequate policies and investments are needed and adaptation measures also for establishing a sustainable agricultural sector.

Agricultural growth is constrained by sectoral inefficiencies, which will be worsened by climate change in the future if no adaption actions are taken. Macedonia is very vulnerable to the climate change, due to the high share of agriculture in the economy and due to the limited water availability, sectoral structure and inefficiencies of the sector. In contrast, agriculture contributes very little to overall emissions in Macedonia and is not emissions intensive, due to its structure (WB Group, 2014). Water availability is a critical issue for agriculture with inadequate irrigation which already limits the productivity and climate change expected to worsen the problem. Agricultural output and incomes could be much higher in future decades if climate change adaptation measures are undertaken. Regarding the sustainable development of agriculture, it is considered that the full-time farming could be an ideal form and structure for regulating the crisis, or as an important place for elaboration and testing of new development models adapted to the characteristics of each country, which are now articulated as models of integrated rural development. Actually, today there is a wider approach to the understanding of agriculture, which includes not only primary agricultural production and processing, but also everything that is now called agribusiness. In fact, that is a complex system that rests on countless unbreakable ties and mutual relations of industrial sectors that produce exclusively for agriculture, industrial sectors that process agricultural products, then tourism, trade, crafts etc.

\section{Conclusions and Recommendations}

"Sustainable development is not an abstract concept - it is the roadmap for responsible acts at national level. Climate change imposes the necessity of ecologically innovative approaches to support economic development”. Gjorge Ivanov - President of Macedonia

In accordance with the Macedonia `s President state, it is time for Macedonia to move from input based agriculture to knowledge-based agriculture. To remain competitive and capture new opportunities, Macedonia should move towards climate smart agriculture that seeks to increase productivity and income in an environmentally and socially sustainable manner, strengthen farmers' resilience to climate change, and reduce the sector's contribution to climate change by reducing green house gas emissions and increasing carbon sequestration in the soil. In that direction, the Green Growth and Climate Change Analytic and Advisory Support Program by the World Bank Group was launched in 2011, focused on job creation, inclusive growth, and adaptation to climate change, mitigation of greenhouse gas emissions, and policy reforms and public 
investments. The WB Group activities would involve providing practical techniques in many areas, especially in soil, water, plant, and livestock management, but also innovative practices such as better weather forecasting, early warning systems and risk insurance. Overall, it is about getting existing information and technology into the hands of farmers and developing new technologies such as climate resilient crops and management to meet the demands of a changing climate. However, although significant institutional investments have been made, other policies (importantly those related to agricultural subsidies and allocation to extension services, and research and development) are either not supportive or even counterproductive in this regard. It is thus crucial to develop a new policy framework that will support green growth for Macedonia's agricultural sector over the next decades. Also, other measures should be undertaken in order to use all potential of agriculture and turn it into main driver of the future economic development such as: irrigation system improvements; improved management of arable land; improved pasture management; land consolidation; land market improvement; development of organic agriculture and policy and institutional strengthening to support these activities.

\section{References}

Delgado, C.L., Hopkins, J., Kelly, V.A., Hazell, P., McKenna, A.A., Gruhn, P., Hojjati, B., Sil, H. and Courbois, C. (1994)" Agricultural growth linkages in Sub-Saharan Africa”, US Agency for International Development, Washington, D.C.

Dimitrievski D., Kotevska A., Stamenkovska I. J., Tuna E., Nacka M. (2015), "Macedonia: Agricultural Policy Brief (CAPB)", Faculty of Agricultural Sciences and Food - Skopje, Macedonia. pp.2-13.

Diao, X., Hazell, P. \& Thurlow, J. (2010). The Role of Agriculture in African Development. World Development, vol. 38 (n. 10), pp. 1375 - 1383.

Ericson T. (2005) "The Agricultural Policy of F.Y.R. Macedonia", Swedish University of Agricultural Sciences, Denmark, pp. 19-47.

Fei, J.C. and Ranis, G. (1961) "A theory of economic development". American Economic Review 514, 53365.

Gollin, D. (2010) “Agricultural Productivity and Economic Growth", Handbook of Agricultural Economics, vol. 4 , pp. $3825-3866$

Harris, J., M. Todaro (1970). "Migration, Unemployment and Development: A Two-Sector Analysis." American Economic Review, Vol. 40, pp. 126-42.

Hirschman, A.O. (1958) “The Strategy of Economic Development in Developing Countries", Yale University Press, New Haven, Connecticut, USA.

Johnston, B.F., Mellor, J.W. (1961) “The role of agriculture in economic development", American Economic Review 51, 566-93.

Jorgenson, D.G. (1961) “The development of a dual economy”. Economic Journal 71, 309-34.

Kindleberger, C. (1988) W. Arthur Lewis Lecture: "The Lewis Model of Economic Growth with Unlimited Supplies of Labor", The Review of Black Political Economy, 15-24.

Kindlegerger, C. (1988) W. Arthur Lewis Lecture: "The Lewis Model of Economic Growth with Unlimited Supplies of Labor", Manchester School of Economic and Social Students, 22, 139-191.

Kindleberger, Charles P. (1967), "Europe's Postwar Growth: The Role of Labor Supply", Cambridge, Massachusetts, Harvard University Press.

Kjosev. S. (2015) "Agricultural Policy", University of "Ss. Cyril and Methodius" - Skopje, Macedonia, pp. 26.

Kydd, J., Poulton, C. and et. al. (2000) "Globalisation, agricultural liberalisation, and market access for the rural poor", Wye College, Kent, UK.

Lewis, W. Arthur (1954) "Economic Development with Unlimited Supplies of Labor," Manchester School of Economic and Social Studies, Vol. 22, pp. 139-91. 
Ministry of Agriculture Forestry and Water Economy (2014), "National Strategy for Agriculture and Rural Development (NSARD) 2014 - 2020", Skopje, Macedonia.

Ministry of Economy of the Republic of Macedonia (2005-2009), Foreign Trade Report of Macedonia.

Nurkse, R. (1953). Problems of Capital Formation in Underdeveloped Countries, New York, Oxford University Press.

Ranis, G., Stewart, F., Angeles-Reyes, E. (1990), “Linkages in Developing Economies: A Philippine Study”, ICS Press, San Francisco.

Rosenstein-Rodan, P.N. (1943) "Problems of industrialization of Eastern and South-Eastern Europe", Economic Journal 53, 202-11.

Scitovsky, T. (1954) “Two concepts of external economies", Journal of Political Economy 62, 143-51.

Self, S. \& Grabowski, R. (2007). Economic Development and the Role of Agricultural Technology. Agricultural Economics, vol. 36(3), pp. 395 - 404

SSO. News Release 2016, 2017 Skopje: State Statistical Office of the Republic of Macedonia

Tiffin, R. \& Irz, X. (2006). Is Agriculture the Engine of Growth? Agricultural Economics, vol. 35, pp. 79 - 89

Timmer, C.P., (2002) "Agriculture and economic development. In: Gardner, B. and Rausser, G. (Eds.), Handbook of Agricultural Economics", Elsevier Science, Amsterdam, North Holland.

USAID, Ministry of Economy of the Republic of Macedonia, 2005, 2006.

World Bank (1981). Accelerated Development in Sub-Saharan Africa: An Agenda for Action. International Bank for Reconstruction and Development / World Bank: Washington, USA.

World Bank (2008), World Development Report: Agriculture for Development. International Bank for Reconstruction and Development / World Bank: Washington, USA.

World Bank Group (2014), "FYROM Green Growth Country Assessment”, Washington DC, USA.

WTO (2014), "Trade Policy Review - The Former Yugoslav Republic of Macedonia", WT/TPR/S/290/Rev.1, p. 60. 
